\title{
Due Diligence Procedures and Principles for Financial Analysis and Corporate Governance
}

\author{
Hugh, Grove \\ Accounting and Finance Professor, \\ Daniels College of Business, \\ University of Denver \\ 2101 S. University Blvd. \\ Denver, CO 80208 \\ E-mail: Hugh.Grove@du.edu \\ Mac, Clouse \\ Accounting and Finance Professor, \\ Daniels College of Business, \\ University of Denver \\ 2101 S. University Blvd. \\ Denver, CO 80208 \\ E-mail: Mac.Clouse@du.edu
}

\begin{abstract}
An initial set of seven procedures was developed for assessing a company's common stock. A second set consisting of ten procedures was developed for performing stealth or external financial (forensic) analysis on a company's common stock. Also in this paper, a set of eight corporate governance principles, developed in secret over the course of one year by 13 prominent CEOs of U.S.-based global companies, were elaborated for an analysis of a company's corporate governance practices. The purpose of this paper is to portray how financial analysts or Boards of Directors can use these procedures and principles in helping to assess the viability of the companies they are analyzing or serving and to develop key questions to ask of corporate executives. Thus, the first set of procedures elaborates seven reasons to consider for assessment of a company's stock. The second set of procedures develops ten steps of stealth forensics that can be used to investigate the possibility of financial misconduct or company fraud. The last set of eight principles assesses the strength of corporate governance in a company. The importance of these principles was demonstrated by matching them with the practices of 18 companies that managed to destroy $\$ 1.5$ trillion in market capitalization. All of these twenty-five procedures and principles will help strengthen financial analysis and corporate governance, especially for the role that financial analysts and Boards of Directors have when assessing the value of a company's common stock for investors.
\end{abstract}

Key words: Due Diligence, Financial Analysis, Corporate Governance

JEL: G3 


\section{Introduction}

The following procedures and principles may be used by both financial analysts and Boards of Directors in helping to assess the viability of the companies they are analyzing and to develop key questions to ask the corporate executives about their companies. The first set of procedures deals with reasons to consider selling when assessing a company's stock. The second set of procedures involves the use of stealth forensics to investigate the possibility of financial misconduct by a company. The last set of principles assesses the strength of corporate governance in a company. All three sets of procedures and principles will help strengthen corporate governance, especially for the role of financial analysts and Boards of Directors as the gatekeepers in protecting the value of companies' common stock for investors.

\section{Seven Reasons to Consider Selling When Assessing a Company's Stock}

Aash Shah, a senior portfolio manager at Summit Global Investments and a Securities and Exchange Commission (SEC) registered investment advisor, has offered the following seven reasons to consider for selling a stock (Shah 2017). Both financial analysts and Boards of Directors can use these reasons as methods to help assess the viability of the companies they are analyzing and serving and to help develop key questions for corporate executives.

\section{Business Model Changes}

When there is material change to a company's business model that makes the stock less attractive, it may be a good time to consider selling the stock. For example, Lehman Brothers Forbes' (2013) third greatest fraud of the $21^{\text {st }}$ Century, changed its business model from serving its customers to trading for its own purposes (as did many other global banks which contributed to the 2008 global financial crisis that destroyed $\$ 11$ trillion in market capital). Alternatively, such material change may result from technology, which is rapidly changing. The following four reasons on disruptive innovations elaborate threats to a company's business model.

\section{Company Fundamentals}

If a company's fundamentals, such as earnings, revenue, cash flow, or profit margins show signs of deterioration, it may be time to sell shares. For example, Enron Forbes' (2013) number one greatest fraud of the $21^{\text {st }}$ Century, had its slim profit margin of $2.5 \%$ deteriorate even further to less than $1 \%$ in its last year of existence. The qualities that once made the stock standout may be long gone. Always pay close attention to company fundamentals -the longer one waits to sell, the more significant the losses may become. The ten procedures of stealth forensics for investi- gating a company that are discussed in section II should be used if company fundamentals are deteriorating.

\section{Missing Expectations}

When a company consistently falls short of expectations for earnings and revenue, it is generally a good time to consider liquidating one's position. Regularly missing expectations is a red flag that the management is having difficulty operating the business. Both telecoms, WorldCom and Qwest, Forbes' (2013) sixth and tenth greatest frauds of the $21^{\text {st }}$ Century, with $\$ 180$ billion and $\$ 65$ billion, respectively, in market cap destruction, had such problems.

\section{Disruptive Innovations}

Sometimes a competitor provides an innovation that is disruptive to a specific industry. This could have a real impact on the value of stock an investor may own. For example, Netflix, with its unique business model, put Blockbuster and other movie rental companies out of business and Amazon's online bookstore put other major booksellers out of business. Apple's smartphones have practically destroyed the former industry leader Blackberry. Currently, Amazon's numerous online offerings are destroying the "brick and motor" retailers and Amazon's current market capitalization is larger than the combined market cap of the next largest eight retailers, such as Wal-Mart, Nordstrom, Sears and JC Penny. Sears, once the largest U.S. retailer, announced that it would close almost 200 Sears and Kmart locations in 2017, due to years of losses and declining sales as shoppers have shifted from the mall to the web [Newsmax, 2017]. Amazon is also entering the grocery business and, accordingly, the stock prices of major grocery competitors have been falling. As an investor, it is important to notice when an innovation begins to completely transform an entire industry.

\section{Regulatory Problems}

When a company is under investigation for serious violations, either by the SEC or another regulatory agency, it is likely time to sell one's shares. For example, the SEC investigated HealthSouth, Forbes' (2013) eighth greatest fraud of the $21^{\text {st }}$ Century, for its revenue recognition and expense estimates. $\$ 50$ billion in market cap was subsequently destroyed. Make sure to take the time to learn the basis for potential violations. Not all investigations are going to end badly but be prepared for the worst. It is important to review the news and quarterly reports for signs of trouble. Another indicator is updates to the Risk Factors in a company's filings. The ten stealth forensic procedures, which will be presented in the next section, expand the analysis of a company's regulatory and operating problems, using the example of Valeant Pharmaceuticals International, which had destroyed $\$ 85$ billion in market cap by 2017. (Enron only destroyed $\$ 78$ billion in market cap by 2001.) 


\section{Unexpected Management Changes}

The unexpected or unexplained resignation of key management executives could signal potentially significant internal problems within a company. Without a very convincing reason for the abrupt departure of C-Suite executives, one may consider liquidating one's holdings. The Good, the Bad, and the Ugly examples follow: the Google CFO resigning to spend more time offline; the Enron CEO resigning to spend more time with his family; the Longtop Financial Technologies CEO and founder scurrying back to China when fraud collapsed their U.S. listed Chinese software company and destroyed \$2.4 billion in market cap.

\section{Numerous Acquisitions}

Most companies focus on one or several related businesses. For example, Dell Computers makes, markets, and sells computers. Multiple acquisitions outside of a company's field of expertise could indicate problems in the core business. Companies that try to diversify away from their core business may be an indication of competitive difficulties in their core business. Such companies should be considered candidates for sale. For example, Tyco, Forbes' (2013) ninth greatest fraud of the $21^{\text {st }}$ Century, made numerous acquisitions and wound up destroying $\$ 63$ billion in market cap. Also, just one bad acquisition can destroy the market cap. The merger of AOL and Time/Warner was based upon expectations of cross selling to each other's customers, which ended up not materializing, and instead destroyed $\$ 200$ billion in market cap before Time/ Warner subsequently spun off AOL.

Global Resource Fund is an example of an investment firm successfully applying the first four of these seven reasons or steps, especially the business model changes (step one) and disruptive innovations (step four). The fund has had overweight renewable energy stocks, which have become a core driver of the fund's performance. For example, year-to-date as of June 30, 2017, Solar Edge Technologies was up 50\%; Vestas Wind Systems, the largest wind farm manufacturer in the world, was up 33\%; Solicdad Quimica y Minera de Chile, one of the world's top three lithium producers, was up $16 \%$ (lithium is used to manufacture lithium-ion batteries.); and Siemens Gamesa, a wind turbine manufacturer, was up 15\%. Yearto-date these companies are outperforming the S\&P 500 Energy index while the Global Resources Fund is up 5.3\% [Holmes, 2017].

Business model changes (step one) and disruptive innovations (step four) are also impacting the traditional energy and renewable energy industries. For the first time ever in 2016, natural gas represented a larger share of U.S. electricity generation than coal with natural gas at $34 \%$ compared to $30 \%$ for coal. Also, for the first time in March 2017, wind and solar power made up $10 \%$ of the total U.S. electricity generation. Windfarms in Texas, Oklahoma, Iowa and other states provided $80 \%$ of this $10 \%$ total. Oncor Electric Delivery Company, the largest Texas electricity transmission company with 10 million customers, has renewable energy operations with wind, solar, and battery storage. Warren Buffett's Berkshire Hathaway (BK) has just offered $\$ 9$ million in cash to purchase this company as $\mathrm{BK}$ has in recent years deepened its commitment to renewable energy, especially wind and solar [Stempel, French 2017].

In 2016, there was a record global installation of new renewable capacity with investment in wind and solar double that of coal, gas, and other fossil fuels. In the U.S., solar ranked as the number one source of new electricity generating capacity and renewables are now cheaper than coal. Coal production saw a record decline in 2016 as it fell $6.2 \%$. British Petroleum's chief executive said: "2016 marked the completion of an entire cycle for coal as production and consumption were falling back to levels last seen almost 200 years ago, around the time of the Industrial Revolution, and the United Kingdom recorded its first ever coal-free day in April of this year" [Holmes, 2017].

\section{Stealth Forensics: Where Were the Gatekeepers For Investors?}

This section will apply financial analysis or forensic procedures that can be used to investigate the possibility of financial irregularities from an external or stealth perspective. Afterwards, these procedures can be used to generate important questions that financial analysts and Directors can ask corporate executives. To illustrate the use of these procedures, Valeant Pharmaceuticals will be analyzed as a recent example from 2017 of a firm with a large market cap destruction of $\$ 85$ billion, which exceeded the $\$ 78$ billion of the infamous Enron 2001 scandal.

Valeant Pharmaceuticals International had a business model where it would buy small drug companies that had patents on drugs and then would raise the prices on these drugs, sometimes up to as much as $500 \%$ ! It also took channel stuffing to an extreme. Instead of just shipping drug products to legitimate distributors before they were ordered, which is the typical channel stuffing procedure for early revenue recognition, Valeant created its own distributors to fraudulently recognize revenue. When Valeant's suspicious activities became public, its market cap fell dramatically. As of November 2017, the destruction was $\$ 85$ billion. Ten forensic procedures are described below that indicate fraud or earnings management and related investment risks [Grove, Clouse, 2017]. They are presented in the order of recommended investigation, using the SEC Edgar Database and online searches:

1) Revenue disclosure analysis (required $10-K$ reports to the SEC) revealed that Valeant used distributors that are often a high risk for channel stuffing. Such stuffing was subsequently admitted in Valeant's 2016 8-K report to the SEC for restated financial statements. 
2) Revenue and customer investigations (starting with online searches) found several short seller reports by Citron Research, which uncovered possible phony Valeant revenues from questionable distribution networks, as later admitted in the above 8 - $\mathrm{K}$ report. Citron's online investigations were an extension of the traditional on-site audit investigations, which auditors began to do in 1937. Valeant's major distribution network, Philidor, has since been terminated and Philidor itself has been closed.

3) Competitive analysis (starting with online searches) revealed that Valeant's drug pricing policy was predatory, as opposed to those of other major pharma competitors. This policy is now being investigated by two Congressional committees and other regulatory agencies.

4) Non-GAAP reporting analysis (required $8-\mathrm{K}$ report per SOX) helped reveal Valeant's earnings management strategy. This non-GAAP analysis can be guided by Deloitte \& Touche's ten-question approach, PWC's five-step approach, and the SEC's four examples of guidance for assessing misleading non-GAAP metrics. Valeant appeared to have problems with all nineteen of these items.

5) SEC comment letters analysis (SEC Edgar Database) revealed Valeant's ongoing revenue recognition and disclosure problems as far back as at least 2012.

6) Insider sales examinations (required Form 4 to the SEC within 4 days of selling) revealed both Valeant executives and institutions selling shares (net of minor purchases) of 4.3 million and 13.0 million, respectively, in the prior six months (11/20154/2016).

7) Proxy statements examinations (required DEF $14 \mathrm{~A}$ report to the SEC) revealed many key corporate governance weaknesses for Valeant, such as the CEO duality problem, the unexpected resignations of both top executives and board members, the lack of board independence and diversity, a majority of older directors, and a focus on short-term incentive compensation for both the top executives and board members. Valeant's 8-K report acknowledged corporate governance problems, primarily a "tone at the top" and a short-term performance-based compensation focus, which contributed to the channel stuffing, and early and phony revenue recognition problems.

8) Legal footnote disclosures readings (required $10-\mathrm{K}$ report) revealed that Valeant had 24 ongoing investigations and lawsuits, including a shareholder class action lawsuit filed two days after the 10/21/2015 Citron Research report came out. Find updates on securities class action lawsuits at www. securities.stanford.edu.
9) Financial press online searches found investigations from 2016 of Valeant in both the U.S. Senate and U.S. House of Representatives Congressional hearings that revealed unethical practices concerning Valeant's predatory drug pricing policy.

10) Additional follow-up procedures (required $10-\mathrm{K}$ report) compared Valeant's reporting to different government entities and revealed a significant difference in income tax rates: $16 \%$ in financial reports versus $9 \%$ in tax reports. Both rates were very low since Valeant was the first U.S. pharmaceutical company to use the tax inversion strategy after relocating to Canada, another possible red flag.

\section{Corporate Governance Analysis}

This section identifies the principles that can be used to assess the strength of a company's corporate governance. Weak corporate governance facilitated over $\$ 1.5$ trillion in investment losses in the $21^{\text {st }}$ Century by just 18 , primarily global, public companies. Sir David Tweedy, the former chair of the International Accounting Standards Board, has commented: "The scandals that we have seen in recent years are often attributed to accounting although, in fact, I think the U.S. cases are corporate governance scandals involving fraud" [Tweedy, 2007]. In 2016, thirteen prominent U.S. business leaders from industrial firms (JPMorgan Chase, Berkshire Hathaway, General Motors, General Electric, and Verizon), asset management firms (BlackRock, Vanguard, State Street Global Advisors, Capital Group, J.P. Morgan Asset Management, CPP Investment Board and T. Rowe Price), and an activist investment firm (Valueact Capital) secretly worked for one year to develop corporate governance principles. Their goal was to develop a pathway for corporate governance in the future (Www.governanceprinciples.org 2016).

A financial press commentator said that these principles may set a new standard in American corporate governance and that the stakes could not be higher as over 90 million Americans own U.S. public companies through their investments in mutual funds, retirement plans, and pensions [Gara, 2016]. A corporate governance expert commented on these eight principles: "I think it shifts the burden of proof onto any corporation that doesn't comply and I am delighted the signatories are such influential people" [McGregor, 2016]. To emphasize the importance of implementing these eight benchmarks of corporate governance principles, they are listed below and matched with weak or violated corporate governance of the 18 companies that destroyed over $\$ 1.5$ trillion in market capital [Grove and Clouse, 2017]. 
Table 1. Corporate Governance Principles for 21st Century

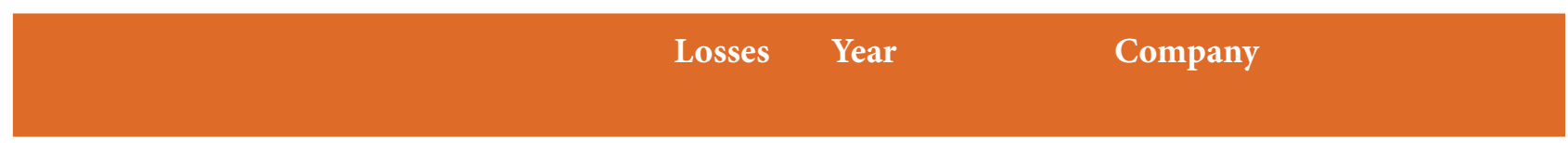

I. Board of Directors: Composition and Internal Governance

a. Composition and Independence

b. Election of Directors

c. Nominating Directors

d. Director Compensation and Stock Ownership

e. Board Committee Structure and Service

f. Director Tenure and Retirement Age

g. Director Effectiveness

\begin{tabular}{c}
$\$ 32$ \\
$\$ 200$ \\
$\$ 24$ \\
\hline$\$ 949$
\end{tabular}

\section{Board of Directors' Responsibilities}

a. Director Communication With Third Parties

b. Critical Activities of the Board: Setting Agenda

\section{Shareholder Rights}
a. Proxy Access
b. Dual Class Voting
c. Written Consent

\section{Public Reporting}

$\begin{array}{lccc}\text { a. Transparency } & \$ 78 & 2001 & \text { Enron } \\ \begin{array}{l}\text { b. Earnings Guidance } \\ \text { c. Long-term Goals }\end{array} & \$ 13 & 2009 & \text { Satyam } \\ \text { d. Long-term Strategic View } & \$ 5 & 2005 & \text { Parmalat } \\ \begin{array}{l}\text { e. Explanations of M\&As and Capital } \\ \text { Expenditures }\end{array} & \$ 200 & 2017 & \text { Valeant Pharmaceuticals } \\ \text { f. Non-GAAP Measures Excluding Equity } & \$ 63 & 2005 & \text { AOL/Time Warner } \\ \text { Compen } & & & \text { Tyco }\end{array}$




\begin{tabular}{|c|c|c|c|}
\hline $\begin{array}{l}\text { V. Board Leadership and Lead Independent } \\
\text { Director }\end{array}$ & $\$ 50$ & 2005 & Health South \\
\hline a. CEO Duality & $\$ 63$ & 2016 & Exxon Mobil \\
\hline b. Strong Lead Independent Director & $\$ 4$ & 2017 & Pershing Square Cap. Mgt. \\
\hline c. Lead Independent Director's Responsibilities & $\$ 626$ & 10 & Companies \\
\hline \multirow{3}{*}{$\begin{array}{l}\text { 21st Century Market Capital Destruction: } \\
\text { Investors }\end{array}$} & $\$ 1,575$ & 18 & Companies \\
\hline & Versus & & \\
\hline & \multicolumn{2}{|c|}{$\begin{array}{c}\text { 21st Century S\&P } \\
500 \text { Index } 76 \% \\
\text { Increase! }\end{array}$} & \\
\hline
\end{tabular}

\section{Management Succession Planning}

a. Senior Management Bench Strength

b. Planning Process

\section{Compensation of Management}

a. Continuity and Long-term Performance Alignment

b. Both Current and Long-term Components

c. Disclosure of Benchmarks \& Perform. Measurements

d. $>50 \%$ Senior Management Compensation: Long-term Equity

e. Articulation of Compensation Plans with Long-term

f. Careful with Large Special Compensation Awards

g. Use of Claw-back Policies for Compensation

\section{Asset Managers' Roles in Corporate Governance}

By not following these eight major principles and benchmarks of corporate governance, just 18 companies had, from 2001 through 2017, over $\$ 1.5$ trillion, combined, in market cap destruction during a period when the S\&P 500 Index had increased by $76 \%$ ! There were two key principles that these companies violated: the first principle which comes from the Board of Directors Composition and Internal Governance, where eight companies destroyed $\$ 949$ billion and the fourth one from Public Reporting, where ten companies destroyed $\$ 626$ billion for a total of $\$ 1.575$ trillion [Grove, Clouse, 2017].

The $\$ 929$ billion of market cap destruction listed by the first key principle was primarily for the 2008 financial crisis, which destroyed $\$ 11$ trillion in market cap worldwide. Only the 2016 Volkswagen ( $\$ 43$ billion) and Wells Fargo (\$24 billion) crises were not directly related, so just the eight banks and other companies listed above destroyed
$\$ 862$ billion in market cap. The Financial Crisis Inquiry Commission (2011) was appointed by the U.S. government with the goal of investigating the causes of the financial crisis of 2008-2009. At the end of January, 2011, the Commission finished its report and concluded: "the greatest tragedy would be to accept the refrain that no one could have seen this coming and thus find nothing could have been done. If we accept this notion, it will happen again." The Commission also concluded that the financial crisis was an "avoidable" disaster caused by widespread failures in government regulation, corporate mismanagement and heedless risk-taking by Wall Street.

Citing dramatic breakdowns in corporate governance that included taking on too much risk, the Commission portrayed incompetence with the following examples. Executives at Citigroup, with an initial market capital destruction of $\$ 240$ billion, conceded that they paid 
little attention to mortgage-related risks. Executives at the American International Group, which had an initial market cap destruction of $\$ 185$ billion, were blind to its $\$ 79$ billion exposure to credit-default swaps. Managers at Merrill Lynch, having an initial market cap destruction of $\$ 200$ billion by its parent, Bank of America, were surprised when seemingly secure mortgage investments suddenly suffered huge losses. The banks hid their excessive leverage with derivatives, off-balance-sheet entities, and other accounting tricks. Their speculations were aided by a giant "shadow banking system" in which banks relied heavily on short-term debt. The Commission concluded that "when the housing and mortgage markets cratered, the lack of transparency, the extraordinary debt loads, the short-term loans, and the risky assets all came home to roost" [Chan, 2011], especially with the $\$ 700$ billion bank bailout by the U.S. government's Troubled Asset Relief Program (TARP). For an example of extraordinary debt loads, the Capital Services, or banking division of General Electric (GE), was about $40 \%$ of GE's total business and it had the same risk issues. Thus, GE initially lost $\$ 200$ billion of its market capitalization after the financial crisis started. In 2016, GE divested itself of this division, explaining that the new higher (8\%) bank capital requirements of the U.S. Dodd-Frank Act were too burdensome for its leveraging strategy. At the time of the financial crisis in 2008, all the major U.S. banks averaged only $3 \%$ capital, or stockholders equity versus $97 \%$ debt [Grove, Clouse, 2017].

Warren Buffett, the U.S. billionaire investor, had an excellent summary of the 2008 global financial crisis. He observed that the "three I's" of every business cycle were especially appropriate for the 2008 financial crisis [Motley Fool staff, 2016]:

1) Innovators, who see opportunity where others don't.

2) Imitators, who take note of what the Innovators are doing and mimic it (with varying degrees of success).

3) Idiots, who jump on the bandwagon far too late with poorly executed attempts to cash in on what everybody else is doing and whose avarice undoes the very innovations they are trying to use to get rich.

Concerning a recent 2016 example of the first key corporate governance principle, Volkswagen managed to destroy $\$ 43$ billion in market cap in just one year after the emission-cheating scandal was disclosed. This oneyear destruction negated the prior three-year market cap increase of $\$ 43.7$ billion. Volkswagen's Board had nine of its 20 directors who were or had been Volkswagen executive managers. If union members and local government officials on the Board are included, there were 14 of 20 or $70 \%$ of non-independent directors. A corporate governance analyst described Volkswagen's Board: "Outside views rarely penetrate. It's an echo chamber" [Stewart, 2015].

Concerning another recent 2016 example of the first key principle, Wells Fargo destroyed \$24 billion in just a few months after its improper sales practices for its retail banking were disclosed in 2016. Customers were encouraged to have many unnecessary bank accounts as Wells Fargo had the slogan: "Eight is Great." Sales practice violations went back to 2002 but were not identified as a "high risk" activity to the Board until February 2014. Also, the Board did not learn until September 2016 (after a settlement with regulators) that, since 2011, 5,300 employees had been fired for opening more than 2 million deposit and credit accounts that customers did not want or know about. Both the CEO and the head of retail banking resigned and had to claw back $\$ 67$ million and $\$ 69$ million, respectively, in stock compensation. A board committee, with the help of an independent law firm, was formed on September 25, 2016, and it concluded that the Board should have centralized its risk function earlier and should have insisted on more concrete and detailed plans to deal with sales abuses and that they should have taken more responsibility. One commentator even observed that the Wells Fargo fiasco raises question of what corporate boards are for [Pender, 2017].

Once again, where were the gatekeepers, especially the financial analysts, Boards of Directors, government regulators, and auditors, to help protect investors? In the above corporate governance summary, just 18 companies were able to destroy $\$ 1.575$ trillion in market cap. Investors should have just invested in an S\&P 500 Index fund, which increased $76 \%$ over the same time period, as Warren Buffett has recommended.

\section{Summary}

After applying seven procedures for assessing a company's common stock, ten procedures were used for performing stealth or external financial (forensic) analysis on a company's common stock. Then, eight corporate governance principles, developed in secret over one year by 13 prominent CEOs of U.S.-based, global companies, were elaborated to analyze a company's corporate governance practices. The purpose of this paper was to demonstrate the use of these procedures and principles by financial analysts and Boards of Directors to help assess the viability of the companies they are analyzing or serving and to help develop key questions to ask of corporate executives.

In this paper, we have discussed multiple procedures that can be used for various assessments of a company's stock. First, we developed seven procedures that can be used to generally assess the common stock of a company. Next, a second set of ten procedures was presented that can be used for a stealth or external financial analysis of a company's common stock. Additionally, we elaborated on a set of eight corporate governance principles that can be used to analyze a company's corporate governance practices. These principles had been developed secretly over the course of a year by a group of 13 prominent CEOs from U.S. based companies working on a global level. Based on these principles, we wanted to provide a helpful scheme for financial analysts and Boards of Directors to use when 
assessing the viability of companies and to provide a set of key questions that they can ask a company's corporate executives.

Thus, the first set of procedures elaborated seven reasons to consider selling when assessing a company's stock. The second set of procedures developed ten steps of stealth forensics to investigate the possibility of financial misconduct or fraud by a company. The last set of eight principles assessed the strength of corporate governance in a company. The importance of these principles was demonstrated by matching them with the practices of just 18 mainly global companies that managed to destroy $\$ 1.5$ trillion in market capitalization. All of these twenty-five procedures and principles will help strengthen financial analysis and corporate governance, especially for the role of financial analysts and Boards of Directors in assessing the value of a company's common stock for investors.

But, how can financial analysts and Boards of Directors spend so much time investigating any or all of the key procedures and questions? The way a U.S. senator operates may provide some strategies and guidance. U.S. senators are constantly bombarded with requests for their time, but they have the advantage of having staff to help them out. For example, Minnesota senator Al Frankein has a staff of 40 people who prepare briefing books on key issues, summarize the results of Senate committee hearings, and act as gatekeepers for his time [Frankein, 2017]. Surely, busy Board of Directors members could hire one or more people as their personal staff. This way they would be provided with the same assistance as U.S. senators in order to further strengthen corporate governance, as opposed to some who treat such Directorships as mere honorary positions. After all, non-employee directors were being compensated quite nicely, as shown by the median pay at 300 companies in 2016: $\$ 260,000$ by large cap companies, $\$ 200,000$ by mid-cap companies, and $\$ 145,000$ by small-cap companies [Graves, Kohn, 2017].

As one executive summary approach to due diligence, financial analysts and Board of Directors and/or their personal staff members could apply the approach of Jim Chanos, the U.S. billionaire short seller, who was among the first to short both Enron ( $\$ 78$ billion market cap destruction by 2001) and Valeant Pharmaceuticals (\$85 billion market cap destruction by 2017). Chanos (2017) has five key steps for analyzing a company's performance and then shorting the company's stock if it fails these five steps:

1) Return on Invested Capital is less than Weighted Average Cost of Capital (the company is selfliquidating).

2) Negative Cash Flow.

3) Highly Levered versus Adequacy of Shareholder Capital.

4) Many Senior Executives leave the company over a short period of time.

5) Opaque and Inadequate Financial Disclosures.
6) These five Chanos steps are primarily financial procedures, except for the fourth one, which is actually a corporate governance analysis. For example, when the CEO of Enron, Jeff Skilling, unexpectedly resigned, Chanos said that it was a nonfinancial or corporate governance red flag for possible fraud, observing that this incident was like a "rat leaving a sinking ship." The same thing happened with Valeant Pharmaceuticals as the CEO and the entire Board of Directors unexpectedly resigned.

\section{References}

Chan, S. (2011) Financial Crisis Was Avoidable, Inquiry Finds. The New York Times, January 25.

Chanos, J. (2017) History of Financial Market Fraud: A Forensic Approach. MGT 848, Yale School of Management, Spring.

Commonsense Principles of Corporate Governance (2016). URL: www.governanceprinciples.org.

Forbes (2013) The 10 Biggest Frauds in Recent U.S. History, August 9.

Frankein, A. (2017) Giant of the Senate. Hachette Book Group.

Gara, A. (2016) The Blueprint to Get Corporate America and Wall Street Up to its Game. Forbes, July 21.

Graves, E., Kohn, K. (2017) 2016 Director Compensation Report, FW Cook.

Grove, H., Clouse, M. (2017) Weak Corporate Governance and \$1.5 trillion of Investment Losses. Corporate Ownership and Control, Fall, Vol. 15, Iss. 1, pp. 298-309.

Grove, H. Clouse, M. (2017) The Role of Risk Management in Corporate Governance: Guidelines and Applications. Risk Governance and Control-forthcoming.

Holmes, F. (2017) Does Coal Stand a Chance Against Renewable Energy? Green Business, Oil \& Energy, June 22. McGregor, J. (2016) These Business Titans are Teaming Up for Better Corporate Governance. The Washington Post, July 21.

Motley Fool staff (2016) Great Quotes: Warren Buffett's 3 I's of Every Business Cycle. URL: www.the-motley-fool. com, June 6.

Newsmax Finance (2017) Sears, Kmart Face Retail 'Armageddon' With 43 More Closings, July 7.

Pender, K. (2017) Wells Fargo Fiasco Raises Question of What Corporate Boards are For. San Francisco Chronicle, April 22.

Shah, A. (2017) 9 Signs that It's Time to Sell a Stock. Newsmax Finance, June 26.

Stempel, J., French D. (2017) Buffett Bets Big on Energy with \$9 Billion Oncor Buy. Reuters, July 7.

Stewart, J. (2015) Problems of Volkswagen Start in the Boardroom. The New York Times, September 24.

Tweedie, D. (2007) Simplifying Global Accounting. Journal of Accountancy, July, pp. 36-39. 